Available online on 15.09.2020 at http://jddtonline.info
Open Access to Pharmaceutical and Medical Research
unrestricted non-commercial use, provided the original work is properly cited

Open $\odot$ Access

Research Article

\title{
Development and Evaluation of Matrix Type Transdermal Patches of Torasemide
}

\author{
Ashish Kumar*, Kapil Kumar \\ Global Institute of Pharmaceutical Education and Research, Kashipur, Uttarakhand, India
}

\begin{abstract}
TDDS manufacture has numerous benefits over other routes like oral delivery. It avoids limitations linked with g.i.t. absorpt ion, enzyme effect, interaction with drug and food. This route is suitable when patient is suffering from vomiting and diarrhea. Torasemide is a loop diuretic; it comes under category of sulfonyl urea. It is prescribed in the treatment of edema, CHF, and hypertension. Whenever it is use d by oral route, it is associated with many side effects like vomiting, nausea, anorexia, and increased appetite. All transdermal patches were transparent and free from any particle. Release profile of twelve batches of Torasemide was done by the means of Franz cell for 7 hrs. Maximum release was shown by MTP6 (71.28 \pm 0.19$)$ and least in formulations of batch code MTP7(24.47 \pm 0.04$)$. In-vitro release data were plotted in 2 different models i.e. first and Korsemeyer peppas. It was observed that release was governed by the diffusion process. On basis of different properties MTP1 batch was found to be optimum. Study concludes that by the means of patches Torasemide can be administered efficiently.
\end{abstract}

Keywords: Torasemide, transdermal patches, HPMC, in-vitro release, stability studies, TDDS

Article Info: Received 09 July 2020; Review Completed 18 Aug 2020; Accepted 27 August 2020; Available online 15 September 2020

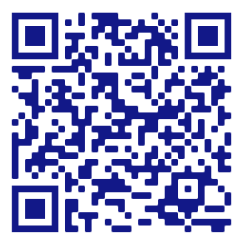

\section{Cite this article as:}

Kumar A, Kumar K, Development and Evaluation of Matrix Type Transdermal Patches of Torasemide, Journal of Drug Delivery and Therapeutics. 2020; 10(5):98-104 http://dx.doi.org/10.22270/jddt.v10i5.4274

*Address for Correspondence:

Ashish Kumar, Global Institute of Pharmaceutical Education and Research, Kashipur, Uttarakhand, India

\section{INTRODUCTION}

Since previous years there are changes at major level in formulation technology. Innovations in drug delivery systems are not only related with novel pharmaceutical dosage forms but also resulted in development of new formulation for the treatment using existing drugs ${ }^{1}$. These innovations in drug delivery system offer advantages, like improved patient compliance, maintaining steady state concentration levels of drug for prolonged period, reduced dosing frequency, and reduced side effects. TDDS manufacture has numerous benefits over other routes like oral delivery ${ }^{2}$. It avoids limitations linked with g.i.t. absorption, enzyme effect, interaction with drug and food. This route is suitable when patient is suffering from vomiting and diarrhea. Reduced frequency of dose administration, and self medication is possible. Since ancient time, skin is used by humans to apply different types of substances for the intention of therapeutic effect ${ }^{3}$. In $20^{\text {th }}$ century, skin is used for longer duration of delivery of different dosage forms. TDDS deliver drugs through skin. Transdermal Patch (TDP) is an adhesive system that is used after placing at skin surface 4 . By the means of patches use of syringe as in parenteral routes can be avoided. That is associated with pain and thus not comfortable for patient specially children. TDP were first developed in the 1970s, and got approval through FDA in 1979. Initially these were limited for motion sickness having scopolamine. Later on TDP are continuously used for different purposes ${ }^{5,6}$.

Based on the amount of drug, patches are used over the skin for 1 to 7 days. In general drug is kept in large dose inside the patch, to place over the skin for a longer time. By the means of diffusion process, the drug goes directly to the blood via the skin. Drug continuously diffuses to the skin as there is large concentration is present in patch ${ }^{7}$. TDP contain membrane that controls the release of drug8-11.

Torasemide is a loop diuretic; it comes under category of sulfonyl urea. It is prescribed in the treatment of edema that is related with renal disease, $\mathrm{CHF}$, or hepatic disease 12,13 . It is also recommended for the hypertension treatment. Whenever it is used by oral route, it is associated with many side effects like vomiting, nausea, anorexia, and increased appetite. Since this drug is used for the long term duration, so patient compliance is very necessary aspect prior to use of this drug. Furthermore Torasemide is having short half life about $3.5 \mathrm{hr}$, so that there is need of frequent drug administration to maintain the therapeutic level ${ }^{14}$. Matrix types of TDP are having advantages over others like easy to prepare without use of any sophisticated instrument and difficult procedure. Due to all these issues related with 
Torasemide, it is a suitable candidate to prepare TDP to get controlled release and to avoid side effects and frequent administration.

\section{MATERIALS AND METHODS}

Torasemide was obtained as gift sample from Schwitz Biotech. Memnagar, Ahmedabad, Gujrat, PG (Propylene glycol), Glycerine, PVP K30 were obtained from CDH, Delhi. Chitosan was obtained from Central Institute of Fisheries, Cochin as gift sample. HPMC K100 (gms) from Cipla Maharshtra and Ethyl cellulose from Asia private ltd.Goa were obtained. All other ingredients were of analytical grade.

\section{Formulation development:}

Torasemide was mixed with solvent plasticizer, penetrations enhancer and polymers according the mentioned ratio. The whole mixture was transferred to a petri dish having area of $55 \mathrm{~cm}^{2}$. In oven petri dishes, placed for $10 \mathrm{hrs}$ with $40{ }^{\circ} \mathrm{C}$ temperature. In order to facilitate evaporation of the solvent, a funnel in inverted form placed over the solution. The prepared film was retrieved by the means of a blade and neutralized by $\mathrm{NaOH}(2 \%)$. After it patches were stored in a desiccators for further use. Total of 12 formulations of TDP were prepared 15 .

\section{Evaluation of TDP}

\section{Physical Properties}

\section{Thickness}

Screw gauge was use for the measurement of the thickness of matrix patches 16 .

\section{Weight Uniformity}

Five matrix patches having area of $2.009 \mathrm{~cm}^{2}$ were selected and weighed. Average wt was calculated ${ }^{17}$.

\section{Content Uniformity}

Matrix patches having area of $2.009 \mathrm{~cm}^{2}$, dissolved in $10 \mathrm{ml}$ buffer. Later on \% drug estimated through UV spectrophotometer at $232 \mathrm{~nm}^{44}$ and by using prepared standard curve of the Torasemide ${ }^{18}$.

\section{Folding Endurance}

Matrix patches were folded many times at fixed position until their breakage. This test is for the estimation of elasticity of patches ${ }^{19}$.

\section{5. \% ML ( \% Moisture Loss)}

Patches placed in a desiccators, having anhyd. $\mathrm{CaCl}_{2}$, with 80-90\%RH. Samples were taken from the desiccators after three days and weighed for the estimation of change in wt. Following equation was used to find $\% \mathrm{ML}^{20}$.

$$
\% \mathrm{ML}=\frac{\mathrm{WI}-\mathrm{WF}}{\mathrm{WI}} \mathrm{X} 100
$$

Where, WI=Weight Initial, WF= Weight Final

\section{6. \% MC ( Moisture Content)}

At room temperature, Patches placed in desiccators, having silica. Patches were taken from desiccators, with 80$90 \% \mathrm{RH}$. and weighed continuously until a constant wt is shown by the patches ${ }^{21}$. Following equation was used to find $\% \mathrm{MC}$

$$
\% \text { Moisture content }=\frac{\mathrm{WI}-\mathrm{WF}}{\mathrm{WI}} \mathrm{X} 100
$$

Where, WI=Weight Initial, WF= Weight Final

\section{7. \% MA (Moisture Absorption)}

Patches placed in a desiccators, with $100 \mathrm{ml}, \mathrm{AlCl}_{3}$ (79.50\% $\mathrm{RH})$. Samples were taken from the desiccators after three days and weighed for the estimation of change in wt. Following equation was used to find $\% \mathrm{MA}^{22}$.

$$
\begin{gathered}
\% \text { Moisture absorption }=\frac{\mathrm{WF}-\mathrm{WI}}{\mathrm{WI}} \mathrm{X} 100 \\
\text { Where, WI=Weight Initial, WF= Weight Final }
\end{gathered}
$$

\section{WVTR (Water vap. transmission rate)}

Same size Vials were used as the cells, cleaned, and dried. $\mathrm{CaCl}_{2}(1.0 \mathrm{gm})$ added to cells, patches having area $2.076 \mathrm{~cm}^{2}$ were placed at the brim. After weighing cells were placed in a desiccator having $\mathrm{KCl}$ with humidity $80-90 \%$. Cells were withdrawn and weighed daily for 7 days. WVTR was calculated using below equation ${ }^{23}$

$$
\text { WVTR }=\frac{\text { WF }- \text { WI }}{\text { TXA }} \times 100
$$

Where, WI=Weight Initial, WF= Weight Final, $\mathrm{T}=$ Time, $\mathrm{A}=$ Area

\section{Flatness}

Matrix patches of length of $1.5 \mathrm{~cm}$ were cutted from the prepared film. After it, the differences in length due to flatness uniformity was estimated by the below formula-

$$
\text { Constriction }(\%)=\frac{\mathrm{LF}-\mathrm{LI}}{\mathrm{LI}} \mathrm{X} 100
$$

Where, LF = length final, and LI = length initial

Patches showing $0 \%$ constrictions were considered to possess $100 \%$ flatness 24 .

\section{In-vitro release studies}

For this study, locally fabricated Franz cell was used. This cell consists of donor and receptor compartment. A sampling port is attached with the receptor compartment to collect sample for the analysis. Both compartments are attached with rubber bands. Receptor compartment was filled with buffer of $\mathrm{Ph} 7.4$, and rotated with magnetic bead. A patch was incorporated with aluminum foil. One ml sample was withdrawn periodically for $7 \mathrm{hrs}$ and analyzed by UV spectrophotometer at $232 \mathrm{~nm}$. After each withdrawal of the sample, a fresh buffer was added to it as a replacement 25 .

\section{Drug release kinetic data analysis:}

Release data was evaluated through PCP disso software for the kinetic models. Zero, first, Higuchi's and Peppa's model were studied ${ }^{26}$

\section{2: Stability study}

Based on different evaluation parameters matrix patches of Torasemide of two batches MTP1 and MTP5 were found to be optimum formulations. These two formulations were subjected to accelerated study for the three months at different temperatures. The formulations of two batches MTP1 and MTP5were air tight packed and kept for three months on $40^{\circ} \mathrm{C}(75 \% \mathrm{RH})$. Samples evaluated through UV spectrophotometer at $232 \mathrm{~nm}$ for the absorbance. By the means of the calibration curve the amount of the Torasemide was estimated 27 . 


\section{RESULTS}

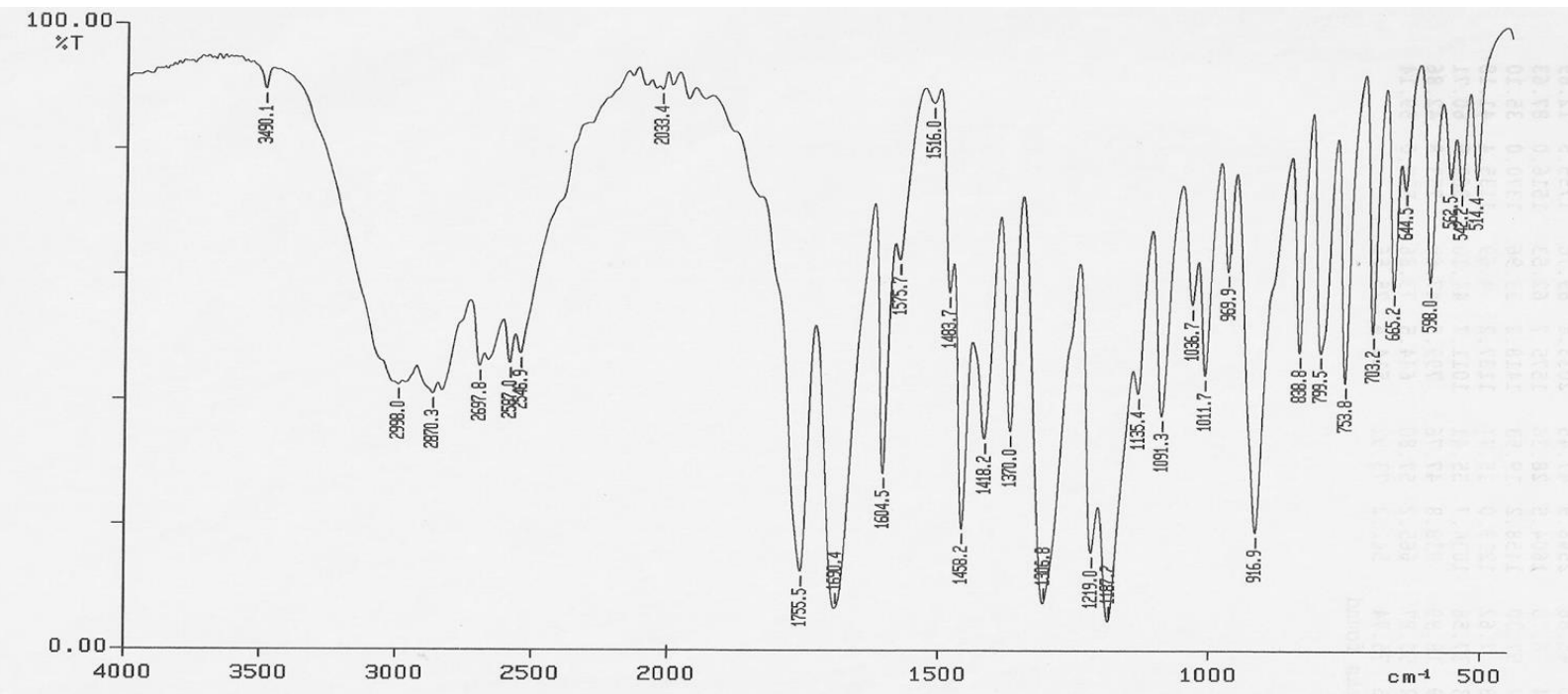

Figure 1: Torasemide FTIR

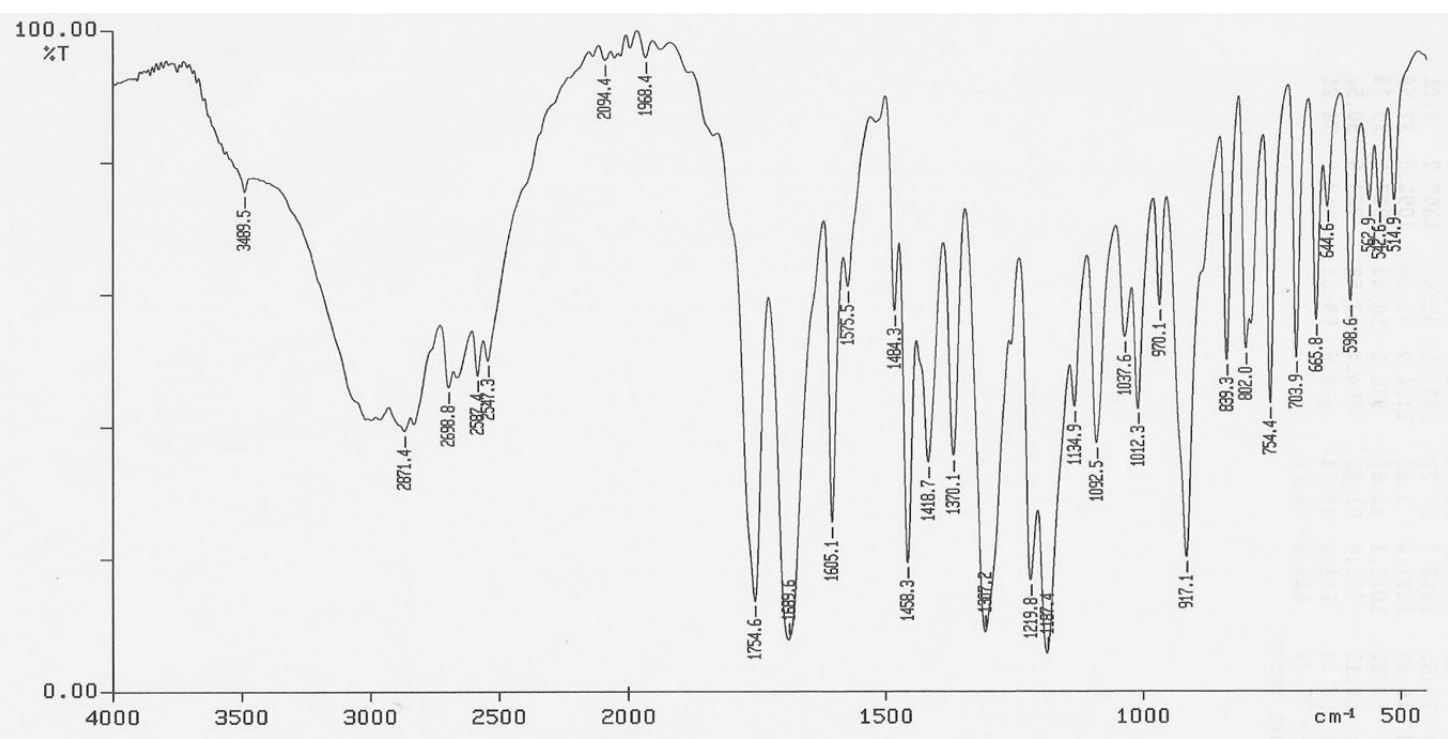

Figure 2: Torasemide +PVP K30+ Chitosan+ Ethyl cellulose+ HPMC FTIR

Table 1: Torasemide Matrix patches formulations composition

\begin{tabular}{|c|c|c|c|c|c|}
\hline Batch & $\begin{array}{c}\text { Torasemide } \\
\text { (mg) }\end{array}$ & Polymer Ratio & $\begin{array}{l}\text { Solvent } \\
(w / v)\end{array}$ & $\begin{array}{c}\text { Propylene } \\
\text { glycol } \\
\text { (Penetration } \\
\text { enhancer) } \\
\end{array}$ & Plasticizer \\
\hline MTP1 & 250 & Chitosan: PVP K30::20:80 & Acetic acid(1\%) & $10 \%$ & $\begin{array}{c}\text { Dibutylphthalate } \\
(30 \%)\end{array}$ \\
\hline MTP2 & 250 & Chitosan: PVP K30::40:60 & Acetic acid(1\%) & - & $\begin{array}{c}\text { Dibutylphthalate } \\
(30 \%)\end{array}$ \\
\hline MTP3 & 250 & Chitosan: PVP K30::60:40 & Acetic acid(1\%) & - & $\begin{array}{c}\text { Dibutylphthalate } \\
(30 \%)\end{array}$ \\
\hline MTP4 & 250 & Chitosan: PVP K30::80:20 & Acetic acid(1\%) & - & $\begin{array}{c}\text { Dibutylphthalate } \\
(30 \%)\end{array}$ \\
\hline MTP5 & 250 & Chitosan :EC:: 20:80 & Dichloromethane (2\%) & $10 \%$ & $\begin{array}{c}\text { Dibutylphthalate } \\
(30 \%)\end{array}$ \\
\hline MTP6 & 250 & Chitosan :EC:: 40:60 & Acetic acid(1\%) & $10 \%$ & $\begin{array}{c}\text { Dibutylphthalate } \\
(30 \%)\end{array}$ \\
\hline MTP7 & 250 & Chitosan :EC:: 60:40 & Acetic acid(1\%) & - & Glycerine (20\%) \\
\hline MTP8 & 250 & Chitosan :EC:: 80:20 & Dichloromethane (2\%) & - & Castor oil (20\%) \\
\hline MTP9 & 250 & HPMC:PVP K30::20:80 & Dichloromethane (2\%) & - & Castor oil (20\%) \\
\hline TP10 & 250 & HPMC:PVP K30::40:60 & Dichloromethane (2\%) & - & Castor oil (20\%) \\
\hline MTP11 & 250 & HPMC:PVP K30::60:40 & Acetic acid(1\%) & - & Castor oil (20\%) \\
\hline MTP12 & 250 & HPMC:PVP K30::80:20 & Acetic acid(1\%) & - & Castor oil (20\%) \\
\hline
\end{tabular}


Table 2: Properties of Torasemide matrix patches

\begin{tabular}{|l|l|l|l|l|l|}
\hline Code & Physical Appearance & $\begin{array}{l}\text { Thickness } \\
(\mathbf{m m}) \pm \text { SD }\end{array}$ & $\begin{array}{l}\text { Mass Uniformity } \\
\mathbf{( m g )}\end{array}$ & $\begin{array}{l}\text { \% Drug } \\
\text { Content }\end{array}$ & $\begin{array}{l}\text { \% Moisture } \\
\text { Content }\end{array}$ \\
\hline MTP1 & Smooth tough & $0.039 \pm 0.41$ & $44.5 \pm 0.12$ & $95.42 \pm 0.12$ & $2.65 \pm 0.09$ \\
\hline MTP2 & Smooth tough & $0.037 \pm 0.09$ & $43.3 \pm 0.08$ & $96.42 \pm 0.09$ & $2.69 \pm 0.16$ \\
\hline MTP3 & Smooth flexible but wrinkled & $0.040 \pm 0.21$ & $42.7 \pm 0.08$ & $94.42 \pm 0.09$ & $2.59 \pm 0.16$ \\
\hline MTP4 & Smooth tough & $0.038 \pm 0.08$ & $46.2 \pm 0.11$ & $95.41 \pm 0.21$ & $2.45 \pm 0.13$ \\
\hline MTP5 & Smooth flexible but wrinkled & $0.036 \pm 0.19$ & $45.7 \pm 0.14$ & $97.35 \pm 0.32$ & $2.55 \pm 0.15$ \\
\hline MTP6 & Smooth flexible but wrinkled & $0.040 \pm 0.09$ & $47.6 \pm 0.09$ & $97.62 \pm 0.12$ & $3.43 \pm 0.64$ \\
\hline MTP7 & Smooth tough & $0.038 \pm 0.18$ & $44.4 \pm 0.15$ & $96.79 \pm 0.12$ & $3.24 \pm 0.65$ \\
\hline MTP8 & Smooth flexible but wrinkled & $0.041 \pm 0.31$ & $45.1 \pm 0.18$ & $97.65 \pm 0.12$ & $3.45 \pm 0.21$ \\
\hline MTP9 & Hard and tough & $0.051 \pm 0.09$ & $43.2 \pm 0.23$ & $96.31 \pm 0.15$ & $3.35 \pm 0.24$ \\
\hline TP10 & Smooth tough & $0.037 \pm 0.19$ & $45.7 \pm 0.11$ & $97.31 \pm 0.32$ & $2.35 \pm 0.16$ \\
\hline MTP11 & Smooth flexible but wrinkled & $0.038 \pm 0.09$ & $46.6 \pm 0.11$ & $97.22 \pm 0.09$ & $3.43 \pm 0.59$ \\
\hline MTP12 & Smooth flexible but wrinkled & $0.041 \pm 0.11$ & $48.7 \pm 0.09$ & $98.45 \pm 0.09$ & $3.79 \pm 0.08$ \\
\hline
\end{tabular}

Table 3: Characterization of Torasemide matrix patches

\begin{tabular}{|l|l|l|l|l|l|}
\hline $\begin{array}{l}\text { Batch } \\
\text { Code }\end{array}$ & \% MA & \% ML & $\begin{array}{l}\text { WVTR } \\
\text { (g/cm } / \mathbf{h r s}\end{array}$ & $\begin{array}{l}\text { Folding } \\
\text { Endurance }\end{array}$ & Flatness \\
\hline MTP1 & $6.442 \pm 0.07$ & $2.881 \pm 0.09$ & $2.327 \mathrm{X} 10^{-4} \pm 0.11$ & $>254$ & $100 \%$ \\
\hline MTP2 & $5.328 \pm 0.89$ & $3.452 \pm 0.08$ & $2.428 \times 10^{-4} \pm 0.13$ & $>235$ & $100 \%$ \\
\hline MTP3 & $4.355 \pm 0.09$ & $2.824 \pm 0.11$ & $2.631 \times 10^{-4} \pm 0.14$ & $>264$ & $100 \%$ \\
\hline MTP4 & $5.482 \pm 0.11$ & $3.232 \pm 0.12$ & $2.747 \times 10^{-4} \pm 0.09$ & $>278$ & $100 \%$ \\
\hline MTP5 & $6.784 \pm 0.09$ & $3.431 \pm 0.14$ & $2.832 \times 10^{-4} \pm 0.08$ & $>265$ & $100 \%$ \\
\hline MTP6 & $7.108 \pm 0.21$ & $3.759 \pm 0.09$ & $1.458 \times 10^{-4} \pm 0.14$ & $>267$ & $100 \%$ \\
\hline MTP7 & $6.231 \pm 0.32$ & $3.545 \pm 0.08$ & $1.871 \times 10^{-4} \pm 0.21$ & $>282$ & $100 \%$ \\
\hline MTP8 & $8.132 \pm 0.41$ & $3.639 \pm 0.14$ & $1.562 \times 10^{-4} \pm 0.09$ & $>257$ & $100 \%$ \\
\hline MTP9 & $8.108 \pm 0.09$ & $3.559 \pm 0.21$ & $1.358 \times 10^{-4} \pm 0.21$ & $>260$ & $100 \%$ \\
\hline TP10 & $7.784 \pm 0.11$ & $3.531 \pm 0.12$ & $1.832 \times 10^{-4} \pm 0.11$ & $>257$ & $100 \%$ \\
\hline MTP11 & $5.355 \pm 0.32$ & $3.824 \pm 0.18$ & $2.531 \times 10^{-4} \pm 0.16$ & $>253$ & $100 \%$ \\
\hline MTP12 & $6.328 \pm 0.29$ & $3.552 \pm 0.11$ & $1.428 \times 10^{-4} \pm 0.14$ & $>247$ & $100 \%$ \\
\hline
\end{tabular}

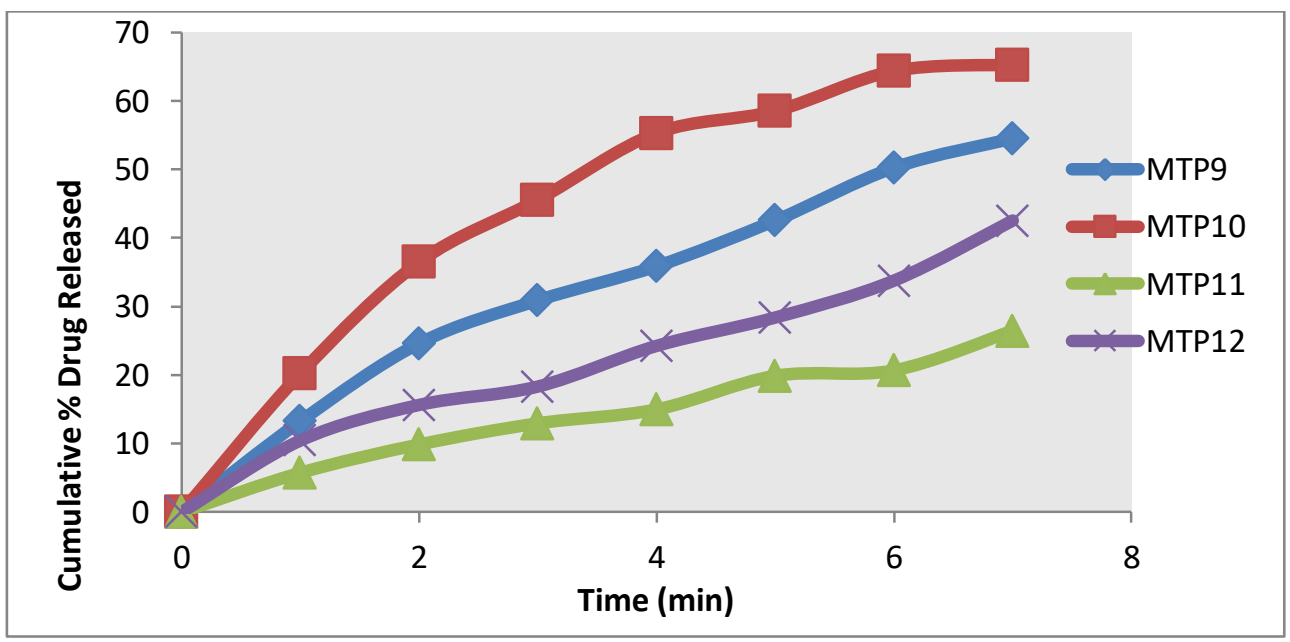

Figure 3: In vitro study of patches (MTP1 to MTP4) 


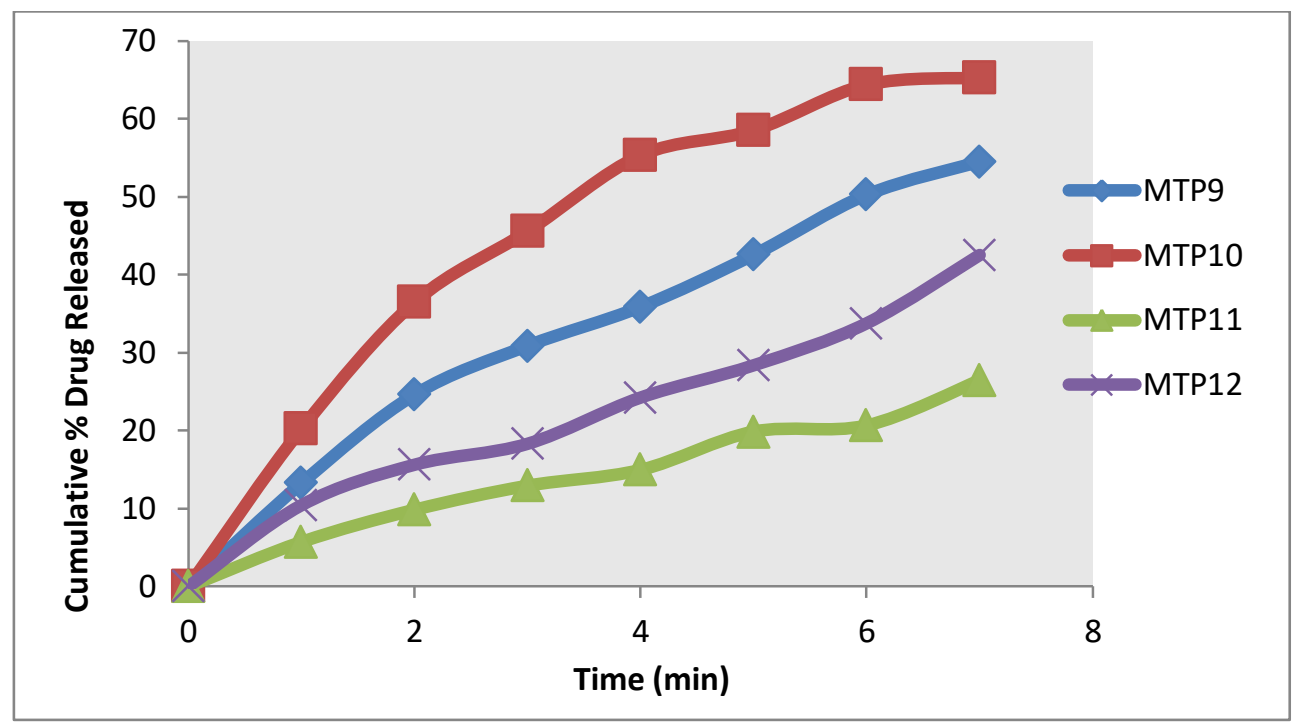

Figure 4: In vitro study of patches (MTP5 to MTP8)

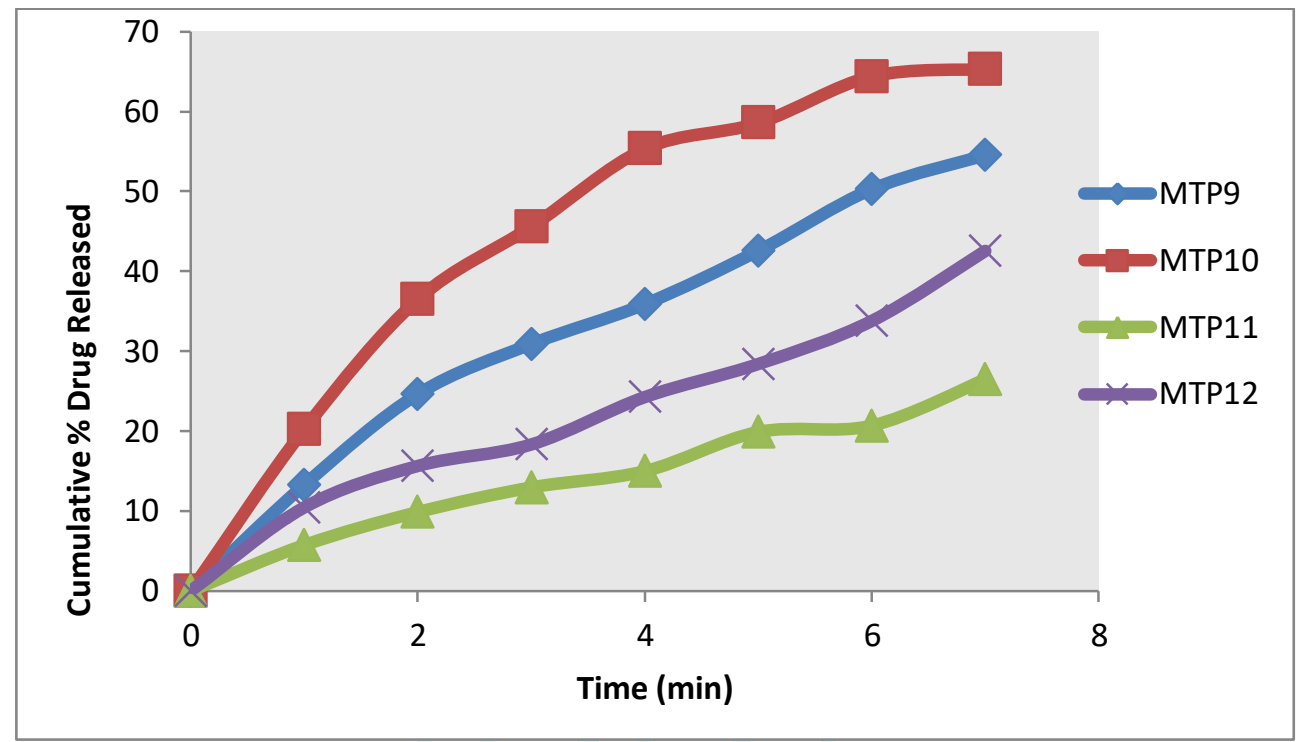

Figure 5: In vitro study of patches (MTP9 to MTP12)

Table 4: Different release models for Torasemide transdermal patches

\begin{tabular}{|l|l|l|}
\hline Batch & Kinetic model & Parameters \\
\hline MTP1 & Peppas and Korsmeyer & $\mathrm{R}=0.972, \mathrm{~K} 1=7.642, \mathrm{n}=0.732$ \\
\hline MTP2 & Peppas and Korsmeyer & $\mathrm{R}=0.971, \mathrm{~K} 1=7.442, \mathrm{n}=0.762$ \\
\hline MTP3 & First order & $\mathrm{R}=0.962, \mathrm{~K} 1=5.61, \mathrm{n}=0.760$ \\
\hline MTP4 & Peppas and Korsmeyer & $\mathrm{R}=0.954, \mathrm{~K} 1=-0.070$ \\
\hline MTP5 & Peppas and Korsmeyer & $\mathrm{R}=0.974, \mathrm{~K} 1=5.2154, \mathrm{n}=0.864$ \\
\hline MTP6 & Peppas and Korsmeyer & $\mathrm{R}=0.983, \mathrm{~K} 1=6.712, \mathrm{n}=0.782$ \\
\hline MTP7 & Peppas and Korsmeyer & $\mathrm{R}=0.955, \mathrm{~K} 1=4.284, \mathrm{n}=0.760$ \\
\hline MTP8 & Peppas and Korsmeyer & $\mathrm{R}=0.963, \mathrm{~K} 1=8.243, \mathrm{n}=0.718$ \\
\hline MTP9 & Peppas and Korsmeyer & $\mathrm{R}=0.975, \mathrm{~K} 1=-0.034$ \\
\hline MTP10 & First order & $\mathrm{R}=0.984, \mathrm{~K} 1=3.157, \mathrm{n}=0.864$ \\
\hline MTP11 & Peppas and Korsmeyer & $\mathrm{R}=0.975, \mathrm{~K} 1=5.846, \mathrm{n}=0.863$ \\
\hline MTP12 & Peppas and Korsmeyer & $\mathrm{R}=0.969, \mathrm{~K} 1=7.451, \mathrm{n}=0.745$ \\
\hline
\end{tabular}




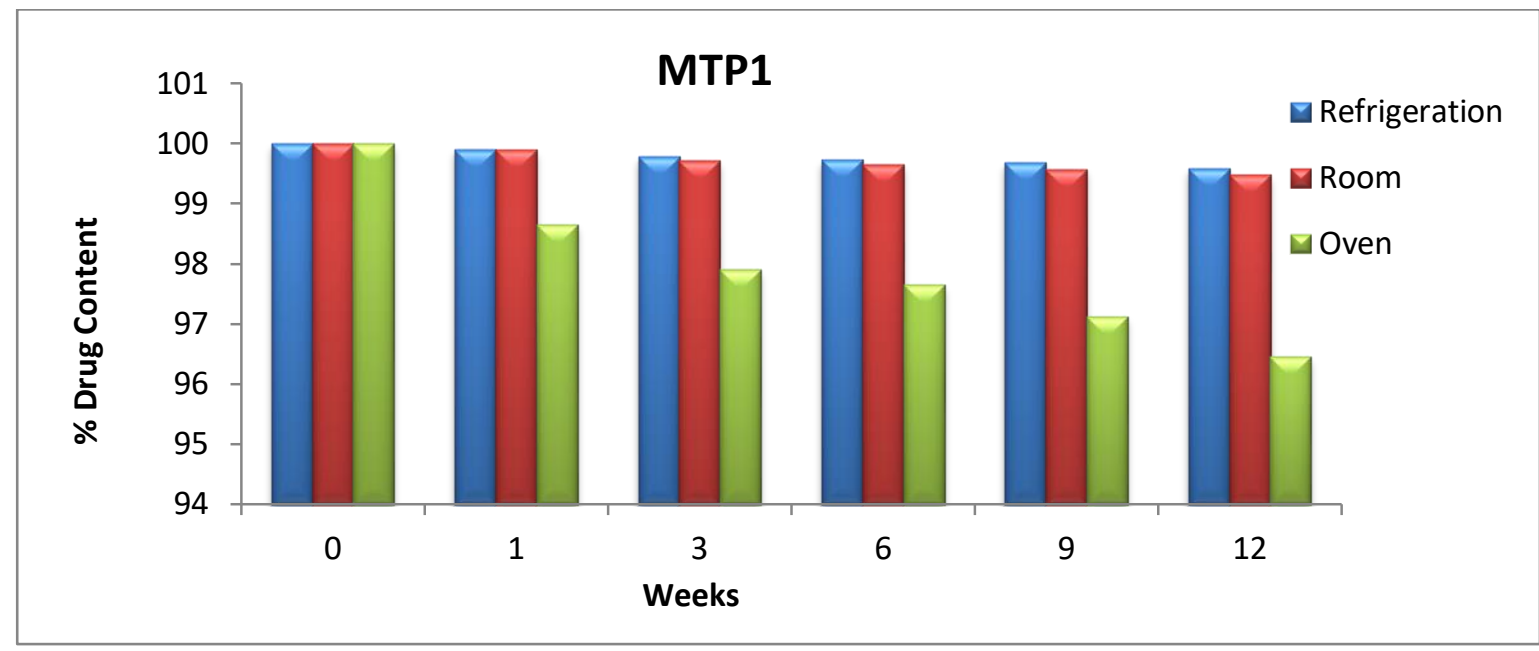

Figure 6: Stability profile of batch MTP1

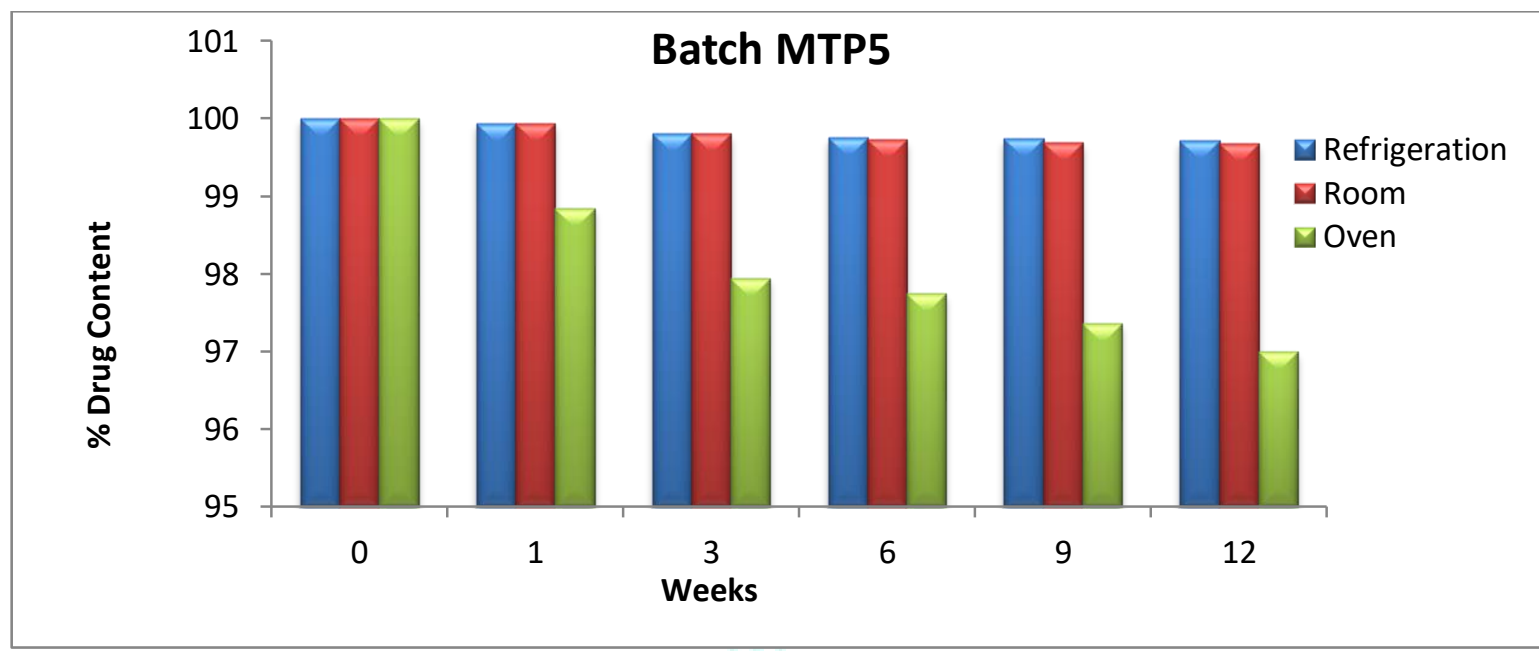

Figure 7: Stability profile of batch MTP6

\section{DISCUSSION}

Torasemide was Schwitz Biotech. Memnagar, Ahmedabad, Gujrat as a Gift sample. The drug was authenticated by different test i.e. solubility, melting point, test according to Indian Pharmacopoeia and analytical methodology was performed on sample to justify the authenticity of sample. The m.p. detected was in the range of $161-165^{\circ} \mathrm{C}$, that is matching as mentioned in IP. This justifies the authenticity of given sample of Torasemide. Torasemide sample was soluble in $\mathrm{H}_{2} \mathrm{O}$, but sparingly in alcohol. This justifies the authenticity of given sample of Torasemide.

Analytical methodology- Given Torasemide sample has shown maximum absorption $\left(\lambda_{\max }\right)$ at $232 \mathrm{~nm}$. FTIR spectroscopy was used to detect any kind of interaction between Torasemide and used polymers i.e. HPMC, EC, PPV K30. No change in peak was found, that indicate compatibility between them.

\section{Development and evaluation of formulations-}

Twelve Torasemide matrix patches were developed using polymers in different ratio and plasticizer and penetration enhancer.

\section{Thickness, weight and $\%$ content:}

Measured thickness of twelve patches was found to be in between $0.037 \pm 0.19-0.051 \pm 0.09 \mathrm{~mm}$. Average thicknesses within a batch was uniform, with a little variation. This difference is because of viscosity difference of polymer solution and also due to absence of temperature control that affect solvent evaporation. Measured weight of twelve patches was found to be in $42.7 \pm 0.08$ to $48.7 \pm 0.09 \mathrm{mg}$. Measured \% drug content found to be $94.42 \pm 0.09$ to $98.45 \pm$ 0.09 .

\section{\% ML, \% MC, \% MA, and WVTR}

$\%$ MA was found to be in the range of $4.355 \pm 0.09$ to 8.132 \pm 0.41 , maximum was observed in MTP8 and minimum in MTP3. \% MC was found to be in the range of $2.35 \pm 0.16$ to $3.79 \pm 0.08$, maximum was observed in MTP12 and and minimum in MTP9. \% ML was found to be in the range of $2.881 \pm 0.09$ to $3.824 \pm 0.18$ maximum was observed in MTP11 and and minimum in MTP1. WVTR was found is maximum in batch code MTP5 i.e. $2.832 \times 10^{-4} \pm 0.08$ and minimum in formulations of batch code MTP9 i.e. $1.358 \times 10$ $4 \pm 0.21$.

\section{Folding endurance-}

It was found maximum in formulation MTP7 $(>282)$ and least in MTP2 (>235). This indicates that due to use of plasticizer, all twelve patches were having sufficient elasticity.

\section{In-vitro release}

Release profile of twelve batches of Torasemide was done by the means of Franz cell for 7 hrs. Largest in batch code MTP6 
$(71.28 \pm 0.19)$ and least in formulations of batch code MTP7(24.47 \pm 0.04$)$. In the initial stage, a rapid release of drug was observed but later on there was a slow and constant release. It was detected that release was inversely proportional to the polymer ratio. Hydrophobic polymer like Chitosan was having poor release as their slow dissolution affect the release of the drug.

\section{Kinetic modeling for transdermal patches -}

Models for the release kinetic profile are shown in Table 10. PCP disso Version 2 software was used in this study. In-vitro release data were plotted in 2 different models i.e. first, and Korsemeyer peppas. It was observed that release was governed by the diffusion process.

\section{Stability study:}

12 weeks study indicates that patch formulation of MTP1 and MTP5 are capable to be stable at $45^{\circ} \mathrm{C}$ as well as at refrigeration temperature. Therefore, the formulations may be kept at room temperature without affecting the properties.

\section{CONCLUSION}

Twelve Torasemide matrix patches were developed using different polymers in different ratio and plasticizer and penetration enhancer. All transdermal patches were transparent and free from any particle. Release profile of twelve batches of Torasemide was done by the means of Franz cell for $7 \mathrm{hrs}$. Maximum release was shown by MTP6 $(71.28 \pm 0.19)$ and least in formulations of batch code MTP7 $(24.47 \pm 0.04)$. In-vitro release data were plotted in 2 different models i.e. first, and Korsemeyer peppas. It was observed that release was governed by the diffusion process. On basis of different properties MTP1 batch was found to be optimum.

12 weeks study indicates that patch formulation of MTP1 and MTP5 are capable to be stable at $45^{\circ} \mathrm{C}$ as well as at refrigeration temperature. Study concludes that by the means of patches Torasemide can be administered efficiently.

\section{REFERENCES}

1. Ashu Mittal, Udai vir singh sara, Asgar ali.Formulation and evaluation of monolithic matrix polymer films for transdermal delivery of nitrendipine. Acta. Pharm. 2009; 59:383-393.

2. Kusum DV, Saisivam S, Maria GR, Deepti PU. Design and evaluation of matrix diffusion controlled transdermal patches of verapamil hydrochloride, Drug Dev. Ind. Pharm. 2003; 29:495503.

3. Limpongsa E, Umprayn K. Preparation and evaluation of diltiazem hydrochloride diffusioncontrolled transdermal delivery system. AAPS PharmSciTech. 2008; 9(2):464-70.

4. Sakellariou P, Rowe RC, White EFT. An evaluation of the interaction and plasticizing efficiency of the polyethylene glycols in ethyl cellulose and hydroxypropyl methylcellulose films using the torsional braid pendulum. Int. J.Pharm.1986; 31:55-64.

5. Costa P, Ferreria DC, Morgado R, Sousa Lobo JM. Design and evaluation of a lorazepam transdermal delivery system, Drug Dev Ind Pharm. 1997; 23:939-944.

6. Dimas DA, Dalles PP, Rekkas DD, Choulis NH. Effect of several factors on the mechanical properties of pressure sensitive adhesives used in transdermal therapeutic systems, AAPS PharmSciTech. 2000; 1:E16.

7. Gabiga H, Cal K, Janicki S. Effect of penetration enhancers on isosorbide dinitrate penetration through rat skin from a transdermal therapeutic system, Int J Pharm. 2000; 199: 1-6.
8. Bhatt P, Lalani R, Vhora I, Patil S, Amrutiya J, Misra A, et al. Liposomes encapsulating native and cyclodextrin enclosed paclitaxel: Enhanced loading efficiency and its pharmacokinetic evaluation. International journal of pharmaceutics. 2018; 536(1):95-107.

9. Elsaied EH, Dawaba HM, Ibrahim EA, Afouna MI. Investigation of proniosomes gel as a promising carrier for transdermal delivery of Glimepiride. Universal Journal of Pharmaceutical Research 2016; 1(2):1-10.

10. Izumoto $\mathrm{T}$, Aioi A, Uenoyana S, Kariyama K, Azuma M. Relationship between the transference of drug from a transdermal patch and physicochemical properties, Chem Pharm Bull (Tokyo) 1992; 40:456-458.

11. Gaur KP, Mishra S, Purohit S and Dave K: Transdermal delivery System: A review. Asian journal of Pharmaceutical and Clinical Research 2009; 2(1):14-20.

12. Miles JA, Hanumanthu BK, Patel K, Chen M, Siegel RM, Kokkinidis DG. "Torsemide versus furosemide and intermediate-term outcomes in patients with heart failure: an updated meta-analysis". J Cardiovasc Med (Hagerstown). 2019; 20(6):379-388.

13. Wargo KA, Banta WM (November 2009). "A comprehensive review of the loop diuretics: should furosemide be first line?". Ann Pharmacother. 43(11):1836-47.

14. Dunn CJ, Fitton A, Brogden RN. "Torasemide. An update of its pharmacological properties and therapeutic efficacy". Drugs. 1995; 49 (1):121-42.

15. Francis DJE. Development and evaluation of matrix type transdermal patches of pioglitazone hydrochloride. Universal Journal of Pharmaceutical Research 2016; 1(1):17-20.

16. Chauhan N, Kumar K, Pant NC. An updated review on transfersomes: a novel vesicular system for transdermal drug delivery. Universal Journal of Pharmaceutical Research 2017; 2(4):42-45.

17. Arunachalam A, Karthikeyan, Vinay Kumar D, Prathap M, Sethuraman S, Ashutosh Kumar S and Manidipa S: Transdermal Drug Delivery System: A review. Current Pharma Research 2010; 1(1):70-81.

18. Amnuaikit C, Ikeuchi I, Ogawara K, Higaki K, Kimura T. Skin permeation of propranolol from polymeric film containing terpene enhancers for transdermal use, Int. J. Pharm. 2005; 289:167-178.

19. Verma PRP, Iyer SS. Transdermal delivery of propranolol using mixed grades of Eudragit: design and in-vitro and in vivo evaluation. Drug Dev. Ind. Pharm. 2000; 26:471-476.

20. Chioma ED. Formulation and evaluation of etodolac niosomes by modified ether injection technique. Universal Journal of Pharmaceutical Research 2016; 1(1):1-4.

21. Durriya Hashmat, Muhammad Harris ShoaibID*, Fatima Ramzan Ali, Fahad Siddiqui. Lornoxicam controlled release transdermal gel patch: Design, characterization and optimization using cosolvents as penetration enhancers. PLOS ONE February 27, 2020

22. B Raja Narender. Formulation and Evaluation of PhysostigmineTransdermal Patch. World Journal of Current Med and Pharm Research., Vol-II, Iss-II, 125-132.

23. Umar S, Onyekachi MK. Development and evaluation of transdermal gel of Lornoxicam. Universal Journal of Pharmaceutical Research 2017; 2(1):15-18.

24. Baghel S, Naved T, Parvez N. Formulation and development of transdermal drug delivery system of ethinylestradiol and testosterone: in vitro evaluation. Int J App Pharm, 2019; 11(1):55-60.

25. Ifrah Jafri Muhammad Harris Shoaib1 - Rabia Ismail Yousuf1 . Fatima Ramzan Ali. Effect of permeation enhancers on in vitro release and transdermal delivery of lamotrigine from Eudragit $\AA$ RS100 polymer matrix type drug in adhesive patches. Progress in Biomaterials 2019; 8:91-100.

26. Kharia A, Gilhotra R, Singhai AK. Formulation and evaluation of transdermal patch for treatment of inflammation. International Journal of Pharmaceutical Sciences and Research. 2019; Vol. 10(5):2375-2384.

27. Fatima AA, Chukwuka UK. Development and in-vitro evaluation of matrix-type transdermal patches of losartan potassium. Universal Journal of Pharmaceutical Research 2017; 2(2):16-20. 